\title{
The Victim's Veto: A Way to Increase Victim Impact on Criminal Case Dispositions
}

\author{
Karen L. Kennard $\uparrow$
}

For every crime committed, there are at least two victims: Society suffers a violation of its laws, and the actual victim suffers an injury to person or property. Yet the American criminal justice systein currently allows only the state to play a meaningful role in the prosecution of a criminal case. While the public prosecutor takes center stage and represents the interests of the state in delivering justice, the actual victim of the crime is relegated to the role of witness for the prosecution. The failure to grant crime victims a prominent role in the dispensation of criminal justice is particnlarly sliortsighted because the continued functioning of the criminal justice system depends on victim cooperation both in reporting offenses and in assisting the prosecution of crimes.

Despite the importance of victim participation to the operation of the criminal justice system, cominentators have observed that crime victims are largely excluded froin the system and that those victims who do participate suffer a "second victimization" at the hands of that systen. The victims themselves have become increasingly dissatisfied with a process that denies them a prominent role in bringing an accused offender to justice. They slow their dissatisfaction by renoving themselves from the system: They fail to report crimes; they fail to appear in court; and at times they resort to vigilantisin. Victim withdrawal from the criminal justice process creates a public impression that the systein is inefficient and unresponsive, and thus exponentially increases the likelihood that nore victims will be deterred from reporting crimes and testifying in court.

In recent years, crime victims frustrated by their limited role in the criminal justice system have agitated for increased access to, and impact on, the criminal justice process. The Victims' Rights Movenent has becoine a prominent national force that has spawned legislative reforns in three main areas: victim compensation, victim satisfaction, and victim

$\dagger$ B.A. 1978, University of California, Santa Barbara; M.A. 1980, University of Minnesota, Minneapolis; third-year student, Boalt Hall School of Law, University of California, Berkeley. The author would like to thank Professors Sheldon Messinger and Franklin Zimring, as well as Alison Keel and Mark Merva, for their guidance and assistance il preparing this Comment for publication. 
impact. ${ }^{1}$ Measuring the effect of such legislation on victim satisfaction is problematic because the relationship between the enactment of a statute and any subsequent changes is always uncertain. Yet, while satisfactionoriented reforms have apparently been marginally successful in facilitating victim participation in the criminal justice systen, impact-oriented reforms have failed to mcrease significantly the ability of victims to affect criminal sentencing dispositions. ${ }^{2}$

The primary reason that impact-oriented reforins have faltered is that the great majority of criminal cases are disposed of through guilty pleas negotiated prior to trial. Plea negotiations are not public, and victims traditionally have been excluded from participation. Experimental atteinpts to involve crime victims in plea negotiations have been infrequent. Moreover, when attempted, these programs have tended to create a rubber-stamp procedure in which the victim essentially acquiesces to a bargam already negotiated by the prosecutor and the defense attorney. The programs have not given victims who participate any opportunity to influence the outcome of their cases. Consequently, it is not surprising that victims do not consistently report that their participation in negotiations mcreased their satisfaction with the criminal justice system. ${ }^{3}$

This Comment suggests a proposal for reform that will allow crime victims to have an impact on the outcome of their criminal cases. The proposal is intended to increase victim satisfaction with the criminal justice system by giving victims the right to veto plea bargain offers that they perceive to be too harsh or too lement. It is hoped that this increased satisfaction will encourage more victims to report crimes and to participate in their prosecution.

1. Victim compensation programs seek to repay victims for the losses they incur due to crime, either through state compensation funds or through repayment from the offenders themselves. Numerous proposals in recent years have recommended restitution for crime victims. These proposals are beyond the scope of this Comment. For more information regarding existing and proposed victim compensation programs, see generally CoNSIDERING THE VICTIM: READINGS IN RESTITUTION AND VICTIM COMPENSATION (J. Hudson \& B. Galaway eds. 1975) [hereinafter CONSIDERING THE VICTIM].

Reforms aimed at improving victim satisfaction seek to mimimize victims' feelings of alienation from the criminal jnstice system by making their participation in the process more comfortable and convenient. Examples of reforms of this type imclude providing separate waiting rooins for victims and defendants, and allowing victims to be on-call when they are scheduled to appear in court. See President's TASK Force on Victims of CRIME, Final Report 72 (Dec. 1982) [hereinafter FinAL REPORT].

Victim impact reforms go a step further and are intended to ensure that crime victims who do participate in the system have a meaningful and effective voice-be it lemient or punitive-in the actual outcome of the criminal case. An example of this type of reform is the ability of crime victims to make an impact statement at the sentencing phase of the trial. See infra notes $48-49$ and accompanying text. This Comment will address reforms of this type.

2. See infra notes $70-80$ and accompanying text.

3. For a discussion of these programs and their effectiveness in increasing victim satisfaction and victim impact on case dispositions, see infra notes 95-108 and accompanying text. 
Part I of this Comment reviews the historical role of the victim in the criminal justice system and evaluates the system's relatively recent rejection of the victim in the context of both the changing American attitudes toward crime and the emergence of the Victims' Rights Movement. Part II examines the reforms that have been enacted to perimit victim impact at the posttrial and pretrial stages of the process, and concludes that these reforms have either been imeffective or present serious constitutional infirmities.

Part III outlines a proposal to allow victims to veto pretrial disposition offers that are unsatisfactorily lement or unnecessarily punitive. The proposal presumes that the prosecutor, in filing criminal charges, has indicated that the state is ready and willing to proceed to trial. Under the terms of this proposal, prosecutors would be required to inform the victim of any plea offer before presenting it to the defense and request the victim's approval. A veto by the victim would be binding on the prosecutor, who would be required either to reformulate the vetoed offer until the victim agrces with its terms or to proceed to trial. Part III concludes by critically evaluating the proposal. It discusses the proposal's constitutionality, presents the pohcy rationales for expanding the role of the victim in the criminal disposition process, and assesses the practical costs and benefits of a victim's veto.

\section{I}

\section{THE RETURN OF THE VICTIM}

Although the crime victim once played a prominent role in the criminal justice process, the modern system of criminal justice almost completely excludes the victim. ${ }^{4}$ The history of the gradual exclusion of victims provides an interesting framework within which to consider the proposal this Comment advocates, a proposal that would return to victims some of the influence they have lost.

\section{A. The Victim as Prosecutor}

During the American colomal period, crime victims were personally responsible for apprehending and punishing criminals. Victims either acted as police and prosecutors or employed others to do so. ${ }^{5}$ Victims made arrests themselves or paid sheriffs to apprehend offenders. The

4. Cardenas, The Crime Victim in the Prosecutorial Process, 9 HaRv. J.L. \& PUB. POL'y 357, 387-88 (1986); see also A. KARMEN, CRIME VICTIMS: AN INTRODUCTION To VICTIMOLOGY 2-3 (1984) (stating that "[n]ow victims are merely bit players, upstaged by the government's prosecutors ...."); Gittler, Expanding the Role of the Victim in a Criminal Action: An Overview of Issues and Problems, 11 PEPPERDINE L. REv. 117, 117 (1984) (noting that "[t]he victims of crime are truly the forgotten people in the American criminal justice system and are all too often victimized twice-first by the crime and then by the system.").

5. See R. Elias, The Politics of Victimization 11-12 (1986); McDonald, Towards a 
victim then hired a private attorney to prosecute the case. Under colonial law, victims were allowed to collect damages from convicted criminals, could bimd offenders into servitude, or could pay the state to incarcerate the perpetrators. ${ }^{6}$

In the nineteenth century, crime control increasingly became a function of government and less the job of the individual parties involved. By the early 1800 s, the system of restitution had been virtually abandoned, due in part to the mcreasing popularity of imcarceration as a form of punishment. ${ }^{7}$ The abandonment of restitution and the establishment of the penitentiary system meant that victims could no longer reap a personal benefit by participating im the criminal justice process. ${ }^{8}$ Moreover, the rise of public police drastically limited the victim's role in the investigation of crimes and the apprehension of criminals. ${ }^{9}$ Finally, the state aggressively took over the meting out of punishment and the collection of fines, eventually eliminating the need for private prosecutors. ${ }^{10}$

As the state increased its responsibility for the investigation and punishment of criminal acts, the legal conception of crime changed. At one time viewed as a private, personal affront, crime came to be seen as an offense agamst the social order. ${ }^{11}$ This conceptual evolution naturally led to the further exclusion of the victim from the criminal justice system. Since crinue by definition was committed against the state, criminal prosecution was solely the state's right and responsibility. Significant involvenient by the victim was seen as inconsistent with, and even a challenge to, that notion. ${ }^{12}$ Eventually, the victim's role in the modern

Bicentennial Revolution in Criminal Justice: The Return of the Victim, 13 AM. CR1M. L. REV. 649, 649 (1976).

6. R. EliAs, supra note 5; see also McDonald, supra note 5, at 651-53.

7. R. Elias, supra note 5, at 12; S. WALkeR, Popular Justice: A History OF AMERICAN CRIMINAL JUSTICE 65-66 (1980); McDonald, supra note 5, at 656-58.

8. See Cardenas, supra note 4, at 371-72; Haller, Plea Bargaining: The Nineteenth Century Context, 13 LAW \& Soc'Y REv. 273, 275 (1979) ("With the abolition of restitution as a standard penalty, the victim lost a direct interest in the outcoine. ... [F]ines or imprisonment were penalties to deter or rehabilitate the offender.").

9. R. ElIAS, supra note 5, at 12; McDonald, supra note 5, at 665-67.

10. R. El1AS, supra note 5, at 12; McDonald, supra note 5, at 659-61. In developing the system of public prosecution, America diverged from the English coinunon law tradition of private prosecution, a practice that coexists with public prosecution in England today. J. JACOBY, THE AMERICAN PROSECUTOR: A SEARCh FOR IDENTTTY 6-11 (1980).

11. A. KARMEN, supra note 4, at 3; Aynes, Constitutional Considerations: Government Responsibility and the Right Not to be a Victim, 11 PePPERD1Ne L. REV. 63, 72 (1984).

12. R. El1AS, supra note 5, at 13. Some commentators have suggested that an unfortunate byproduct of the conception of crime as an offense against the state has been the elimination of informal inechanisms of social crime control, such as negative victinn and coinununity response to offenders. Cf. E. ZIEGENHAGEN, V1CTIMS, CR1ME, AND Social CoNTrol 143 (1977) (referring to various European colonies in noting that "the imposition of Western forms of law on non-Western societies frequently results in a destruction of existing indigenous forms of social control without their effective substitution."). 
system of criminal justice was limited to reporting crimes and testifying as a witness for the prosecution.

\section{B. The Failure of Rehabilitation}

As the legal characterization of crime moved away from the notion of individual injury and toward a concept of societal harm, new penological theories developed that were more socially oriented and less responsive to individual desires for retribution. In the early nineteenth century, a theory of penal reform emerged that emphasized "treating" criminals rather than punishing thein. This "rehabilitative" model gained broad acceptance among American legal scholars and became the dominant penological theory throughout much of the twentieth century. ${ }^{13}$

Underlying the theory of criminal rehabilitation was "the notion that a primary purpose of penal treatinent is to effect changes in the characters, attitudes, and behavior of convicted offenders, so as to strengthen the social defense against unwanted behavior, but also to contribute to the welfare and satisfactions of offenders." 14 The rehabilitative model rejected criminal punishınent in favor of the idea that the propensity to commit crime could be eliminated through individualized treatment. ${ }^{15}$ One natural but unfortunate consequence of this focus on the capacities of the criminal, however, was a decreased concern with the needs of the victim.

Yet after a century of widespread acceptance in this country, much of the support for the rehabilitative model has evaporated. ${ }^{16}$ The factors underlying the failure of rehabilitation are coinplex; no one element einerges as the cause of its decline. One factor of considerable influence was the publication of reports by American criminologists who first systematically studied penal treatment prograins in the 1950s and 1960s and found that criminal recidivism was apparently unrelated to the presence or absence of treatment. ${ }^{17}$ Regardless of the reasons for its collapse,

13. F. Allen, The Decline of the Rehabilitative Ideal 1 (1981).

14. Id. at 2.

15. See American Friends Service Committee, Struggle for Justice 36-37 (1971) [hereinafter STRUGGLE FOR JUSTICE].

The rehabilitation model may be based on the assumption that underlying causes of criminal behavior can be identified; otherwise treatment would be ineffective. Alternatively, the model may assume that treatment might influence criminal behavior even in the absence of any understanding of the causes of such behavior. Some critics of the rehabilitation model reject both sets of assumptions. See id. at 40-42.

16. F. ALLEN, supra note 13 , at 1-2.

17. See A. von Hirsch, PAst or Future Crimes 4 (1985); see generally D. Lipton, R. Martinson \& J. Wilks, THE EfFectiveness of Correctional Treatment: A SURVey of TREATMENT EVALUATION STUDIES 516-32 (1975) (summarizing the results of several studies that have evaluated the effects of various treatment techniques on recidivism).

Various alternative theories have been advanced for the growing disenchantment with the rehabilitative model. Some critics suggest that the failure of rehabilitation was the result of vesting 
however, the fact remains that "[a]fter more than a century of persistent failure, this reformist prescription is bankrupt."18

This climate of declining optimism regarding the possibility of effective criminal rehabilitation helped set the stage for the current reconsideration of the role of the victim in the criminal process. ${ }^{19}$ The efforts of various groups to expand victim participation in the criminal justice system have become popularly known as the Victims' Rights Movement.

\section{The Growth of the Victims' Rights Movement}

The precedimg discussion has shown that, in recent decades, Americans began to sense that the criminal justice system's emphasis on reliabilitation had been ineffective in preventing criminal recidivism. ${ }^{20}$ Additionally, the pubhic increasingly felt that criminal justice officials often gave priority to administrative efficiency over appropriate punishment when disposing of cases. ${ }^{21}$ This change in American attitudes

both the power to punish and the responsibility to treat in the hands of one party. "[T]he inevitable result of blending in the same process the state's adversary interest against the prisoner with its helping role for the prisoner . . . [is] the debaseinent of treatinent." STRUGGLE FOR JUSTICE, supra note 15 , at $26-28$.

Other commentators have suggested that the rehabilitation model failed because we as a society lack sufficient understanding of the ineans of modifying criminal behavior to effectively prevent recidivism through treatment. See F. ALLEN, supra note 13, at 34, 57-58; A. vON H1RSCH, supra, at 4.

Additional criticisms of the rehabilitation model focus on the impossibility of effectively treating a patient who is coerced into receiving treatment, and the difficulty of obtaining adequate state funding for individuals whom society tends to regard as unworthy. See STRUGGLe For Justice, supra note 15, at 11,97. Further, some critics believe that confidence in the possibility of reform is reduced when "a sense of difference and social distance separates the promoters from the subjects of reform." F. ALLEN, supra note 13, at 30-31.

18. STRUGGle FOR JUSTICE, supra note 15, at 8. The American Friends Service Counmittee's harsh criticisin of the rehabilitative unodel is particularly notable since the Quakers were at one time closely associated with the model's emergence and growth in this country. F. ALLEN, supra note 13, at 7 .

The committee's primary objection to the rehabilitative ethic is that it leads to excessive discretion and potential abuses in sentencing. Sentences under this model must necessarily be indeterminate, since the offender theoretically may not be released until he or she is "rehabilitated." This open-endedness in turn leads to excessively lengtliy sentences. STRUGGLE FOR JusTiCE, supra note 15, at 84, 124-25. The committec notes as an exainple the effect of the adoption of rehabilitation in California, which led to an increase in the length of sentences and the number of persons incarcerated with no change in recidivism rates. Id. at 91-92.

19. Public awareness of the failure of rehabilitation is evident from recent public opinion data. In 1970, 73\% of Americans felt that rehabilitation should be the main emphasis in prisons. By 1982, that figure had declined to $44 \%$. BUREAU of JUSTICE STATISTICS, U.S. DEP'T OF JUSTICE SOURCEBOOK OF CRIMINAI JUSTICE STATISTICS 1983261 (1984) [hereinafter SourcebOoK]; see also S. WALKER, supra note 7, at 244 ("By the mid-seventies a profound retreat from rehabilitation swept through public and professional thinking.").

20. See supra notes $17 \& 19$ and accompanying text.

21. See D. Jones, Crime Without Punishment 201 (1979) (alleging that "[m]ost prosecutorial decisions ... are made by underqualified, inexperienced, and career-motivated assistants who beheve it is to their personal advantage to process criminal cases as expeditiously as 
eventually culminated in a national grass roots inovement that advocated increased recognition of victims' rights.

The orignis of the Victims' Rights Movement can be traced to the emergence of the science of victimology in the late 1940s and 1950s. ${ }^{22}$ By 1957, proposals for victim compensation were engendering international public debate. ${ }^{23}$ New Zealand enacted the first victim compensation program in $1963,{ }^{24}$ and two years later California became the first American state to provide compensation for crime victims. ${ }^{25}$ The first International Symposium on Victimology was held in Jerusalem in $1973,{ }^{26}$ and in the mid-1970s the first American victim/witness assistance programs were fornied. ${ }^{27}$

Public interest in victims' rights contimued to grow during the early $1980 \mathrm{s.}^{28}$ President Reagan convened a Task Force on Victims of Crime which pubhshed its first report in $1982 .{ }^{29}$ The report recommended over one hundred victim-oriented refornis aimed at state and federal governinents, the judiciary, and criminal justice professionals. The Task Force also proposed augnientation of the sixth amendment to the Constitution to add language that would grant crime victims the right, "in every crimmal prosecution ... to be present and to be heard at all critical stages of judicial proceedimgs." 30

In 1986, the Justice Department issued a follow-up report on the Task Force's recommendations. ${ }^{31}$ This report indicated that nearly seventy-five percent of the Task Force's imitial recommendations had

possible witlout mucl regard for the public safety . . . "); F. ZiMRING \& R. Frase, The CRIMINAL JUSTICE SYSTEM 495 (1980) ("Few practices in the system of criminal justice create a greater sense of unease and suspicion than the negotiated plea of guilty. ... The offense for which guilt is acknowledged and for which the sentence is imposed often appears almost incidental to keeping the business of the courts moving.").

22. According to Andrew Karmen, Benjamin Mendelsohn coined the term "victimology" in an article written in 1947. A. KARMEN, supra note 4, at 26; see also R. EliAS, supra note 5, at 17. While victimologists study all types of victims, mcluding victims of natural disasters, their work has been incorporated into this Comment only to the extent that it bears upon victims of crime.

23. See A. KARMEN, supra note 4, at 26.

24. See R. Elias, supra note 5, at 18.

25. Carrington \& Nicholson, The Victims' Movement: An Idea Whose Time Has Come, 11 PEPpERdine L. REV. 1, 2 (1984). The original California statute was repealed and redrafted in 1967. For the current California compensation plan, see CAL. Gov'T CoDE §§ 13959-13969.2 (West 1980 \& Supp. 1988).

26. A. KARMEN, supra note 4, at 26.

27. See R. EliAs, supra note 5, at 19; see also Carrington \& Niclolson, supra note 25, at 2 (noting that the National Organization for Victim Assistance was founded in 1976).

28. Carrington \& Nicholson, supra note 25, at 5-10.

29. FINAL REPORT, supra note 1 .

30. Id. at 114 .

31. OfFice of Justice Programs, U.S. Dep'T OF JUSTICE, Four Years LATER: A REPORT on the President's Task Force on Victims of Crime (May 1986) [hereimafter Four Years LATER]. 
been implemented. ${ }^{32}$ Several pieces of legislation enacted during this period clearly demonstrate congressional recognition of the concerns of crime victims. The federal Victim and Witness Protection Act of $1982^{33}$ protects victims from intimidation and harassment by making it a crime to threaten them or retaliate agamst them. The Comprehensive Crime Control Act of $1984^{34}$ contains several victim-oriented provisions, mcluding the Bail Reform Act, which provides that an accused criminal's dangerousness to the commumity may be considered at bail hearings, ${ }^{35}$ and the Victims of Crime Act, which estabhishes a Crime Victims' Fund to match thirty-five percent of the amounts paid by states in victim compensation awards. ${ }^{36}$

There was substantial state legislative activity in the area of victims' rights as well. As of July 1985, thirty-one states had enacted comprehensive laws codifying a significant number of the reforms recommended by the President's Task Force. ${ }^{37}$ These statutes included laws requiring that victims be notified of case developments, mandating victim impact statements at sentencing, assuring the prompt return of seized property, protecting victims from mtimidation and harassment, and providing victim restitution..$^{38}$

Reforms dealing with victim restitution and increasing the responsiveness of the system to the needs of victims are not concerned with affecting case outcomes. Instead, they seek to facilitate and encourage victim participation in the criminal justice system by reducing the discomfort and inconvemence victims presently experience. These provisions typically have not been controversial, because they operate outside the context of criminal due process and primarily implicate resource concerns, such as administrative costs and case management. ${ }^{39}$

This Comment examines those reforms that have gone beyond mere

\footnotetext{
32. Id. at iii.
}

33. Victim and Witness Protection Act of 1982, Pub. L. No. 97-291, 96 Stat. 1248 (codified as amended in scattered sections of 18 U.S.C. (1982 \& Supp. IV 1986)).

34. Comprehensive Crime Control Act of 1984, Pub. L. No. 98-473, tit. 2, 98 Stat. 1976 (codified as ameuded in scattered sections of 18 U.S.C., 42 U.S.C. (1982 \& Supp. IV 1986)).

35. Bail Reform Act of 1984, Pub. L. No. 98-473, tit. 2, § 203(a), 98 Stat. 1976, 1980 (codified at 18 U.S.C. $\S 3142(\mathrm{~g})(4)$ (Supp. IV 1986)).

36. Victims of Crime Act of 1984, Pub. L. No. 98-473, tit. 2, $\S$ 1401-1410, 98 Stat. 2170, 2171 (codified at 42 U.S.C. $\S 10602(a)(1)$ (Supp. IV 1986)).

37. See Four YEARS LATER, supra note 31, at 4 (charting the progress of victim-oriented reforms in the state legislatures between 1982 and July 1985).

38. Id.

39. In fact, the number of victim/witness assistance programs doubled between 1980 and 1986. FOUR YEARS LATER, supra note 31, at 5. Interestingly enough, one reason why this rapid expansion in assistance programs has met with little resistance may be because the programs actually benefit criminal justice officials more than victins. Robert Elias reports that these programs facilitate witness inanagement and reduce institutional costs, but concludes that they provide victims with little actual assistance. See R. ElIAS, supra note 5, at 179. 
recognition of the needs of victims, seeking instead to empower victims with the ability to affect the disposition of their cases. The primary reforms falling in this impact-oriented category mclude the admission of oral or written victim impact statements at parole hearings and at the sentencing phase of criminal trials, and the inclusion of victims in pretrial plea negotiation conferences. Inpact-oriented reforms are susceptible to criticism from those who fear that expanding the victim's role in the criminal process will necessarily infringe upon the constitutional protections provided to the criminal defendant. The following section discusses the constitutionality of these impact-oriented reforms, and critically evaluates their practical effectiveness.

\section{II}

\section{INCREASING VICTIM IMPACT: REFORMS ATTEMPTED AND Challenges Unmet}

The process of criminal justice depends on victims to report crimes and to testify for the state when necessary. ${ }^{40}$ Consequently, to ensure its smooth functioning, the criminal justice system inust avoid alienating victims. ${ }^{41}$ Reform mcasures designed to increase victim impact on the disposition of criminal cases attempt to prevent such alienation. These measures assume that increasing victim impact will satisfy victims, and that increased victim satisfaction will improve the operation of the criminal justice system. ${ }^{42}$

40. See R. ElIAS, supra note 5, at 134 (estimating that approximately $95 \%$ of all reported crimes that involve victims result from citizen coinplaints, often coming from the victims themselves).

41. One cominentator has noted that:

The most frequently voiced complaint concerns impersonality. Victims feel mistreated .... They are interrogated, badgered, summoned, threatened with conteinpt of court for noncooperation, dismissed, and perhaps later recalled without explanation or consultation. Then after the state is through with them, whether their case was won or lost, they are cast adrift to fend for themselves. Those who react angrily to such manipulation by the state exert the only leverage left to them. They discontinue their participation in the process and cut their losses of additional time, money, and pride by dropping out.

A. KARMEN, supra note 4, at 147 (citation omitted); see also M. BARD \& D. SANGREY, THE CRIME VICTIM'S BooK 106-10 (1979) (noting that some victins decide not to report crimes because of a "lack of faith in the police and the courts." Id. at 106.); D. JONES, supra note 21, at 27 (estimating that less than one-third of all crimes against persons in 1975 were reported to the police); Hindelang \& Gottfredson, The Victim's Decision Not to Invoke the Criminal Justice Process, in CRIMINAL JusTICE AND THE VICTIM 65-77 (W. MCDonald ed. 1976) (stating tliat victims decide not to invoke the criminal justice process primarily because they believe nothing can be done).

42. See Hindelang \& Gottfredson, supra note 41, at 57-58; Kelly, Victims' Perceptions of Criminal Justice, 11 PEPPERdINE L. Rev. 15, 20-21 (1984); see also FINAL RePORT, supra note 1, at vi (stating tliat the criminal justice system is "absolutely dependent" on victim cooperation); Schneider, Burcart \& Wilson, The Role of Attitudes in the Decision to Report Crimes to the Police, in CRIMINAL JUSTICE AND THE VICTIM, supra note 41, at 102 (victims of personal crimes, as opposed to property crimes, were somewliat more likely to report the crime if they believed the court was apt to punish the offender). 
Despite the obvious importance of the crime victim to the operation of the criminal justice system, many legal scholars assert that victims currently suffer a "second victimization" at the hands of criminal justice professionals. ${ }^{43}$ The criminal justice system has traditionally placed a low priority on addressing the difficulties, both emotional and logistical, that victims encounter when reporting crimes or testifying in court. A 1976 survey in Alameda County, California, revealed that twelve percent of crime victims were not notified when an arrest was made in their cases, thirty percent never got their property back after it was used as evidence, sixty-one percent of those ehigible for state compensation were never inforned of their right to file a claim, and forty-two percent were never notified of the outcome of their cases. ${ }^{44}$

Victims have become imcreasingly dissatisfied by the lack of attention they receive from the criminal justice system. ${ }^{45}$ The danger of a high level of victim dissatisfaction is that victims will become discouraged from future participation in the criminal justice system. The evidence suggests that this is not an idle concern. Researchers noted in one study that the more experience victim witnesses had with the courts, the more reluctant they were to have any subsequent imvolvement with the criminal justice system. ${ }^{46}$

The Victims' Rights Movement focused public attention on victims' dissatisfaction with their treatment by the criminal justice system, and prompted the enactment of numerous legislative refornis designed to mcrease victim involvement in the process of criminal justice. ${ }^{47}$ Reforn 1 measures were enacted to mcrease victim impact on the outcome of crimmal cases at both the posttrial and pretrial stages of the criminal process. The legal and practical effects of these impact-oriented reforms are discussed in the following sections.

43. See R. EliAs, supra note 5, at 133; McDonald, Criminal Justice and the Victim: An Introduction, in CRIMINAL JUSTICE AND THE VICTIM, supra note 41, at 17-20; $c f$. C. Bartollas, S. Miller \& P. Wice, Participants in american Criminal Justice: The Promise and the Performance 342 \& n.12 (1983) (pointing out that victims "often feel that they are the ones on trial"); L. FORER, CRIMINALS AND Victims 29 (1980) (noting that the victin's role is that of a witness, rather than a party, in our system of criminal justice, making the victim essentially a "nonperson").

44. A. KARMEN, supra note 4, at 148.

45. One commentator imterviewed 100 felony crime victims and concluded that victims "deeply resent being excluded froin dehberations." Kelly, supra note 42, at 18. Another scholar concluded that the victim's "sense of alienation with the criminal justice system has reached such heights that many pieces of literature now discuss the problem in terms descriptive of a crisis." Cardenas, supra note 4 , at 357.

46. M. Knudten, R. Knudten \& A. Meade, Crime Victims and Witnesses as Victims of the Administration of Justice (1975) (Milwaukee: Center for Criminal Justice and Social Policy, Marquette University) (mpublished paper), discussed in DuBow \& Becker, Patterns of Victim Advocacy, in CRIMINAl JustiCe AND THE Victim, supra note 41 , at 151.

47. See supra notes 22-39 and accompanying text. 


\section{A. Reforms at the Posttrial Stage}

Once a defendant's guilt is estabhished at trial, a second phase of the criminal process begins. In this posttrial, or penalty, stage, the judge or jury determines the sentence the convicted defendant will receive. Some reform efforts have attempted to give the victim a more significant role in this stage of the criminal process. In inany states and in the federal system, legislation has been enacted that permits the sentencing judge or jury to review a presentence report during the penalty phase of a criminal trial. A portion of this report, known as a victim impact statement, contains information regarding the financial, physical, and einotional impact of the crime on the victim. ${ }^{48}$ In addition, several states permit the victim or a representative to appear in person at the sentencing hearing and present this information directly to the sentencer. This personal appearance by the victim or the victim's representative is called "allocution."49 The judge or jury inay then consider this impact information im determining the appropriate sentence.

\section{Posttrial Reform: A Legal Analysis}

At first glance, the introduction of victim impact stateinents and victim allocution at the sentencing phase of criminal trials seeins clearly constitutional because the defendant's guilt is already established before the impact information is introduced. For this reason, courts imitially did not feel that admitting such statements would violate a defendant's constitutional right to due process ${ }^{50}$ or the constitutional right to confront adverse witnesses. ${ }^{51}$

48. The Victim Witness Protection Act, Pub. L. No. 97-291, 96 Stat. 1248, 1249 (1982 \& Supp. III 1985) amended Federal Rule of Criminal Procedure 32 to require the inclusion of a victim impact stateinent in the presentence report, which is required at the penalty phase of federal prosecutions. See Fed. R. CR1M. P. 32(c) and Pub. L. No. 92-291, § 2420 (Oct. 14, 1982). For a representative state statute governing victim impact statennents, sec M1CH. CoMP. LAWS ANN. $\$ \S 780.763-780.764$ (West Supp. 1988).

49. See E. Villmoare \& V. Neto, Victim Appearances at Sentencing Hearings UNDER THE CALlfornia Victims' BILl of Rights ix (Mar. 1987).

As of July, 1985, 19 states permitted victim allocution at the sentencing phase of criminal trials, and 39 states required a victim impact statement at this stage of the proceedings. Four YEARS LATER, supra note 31 , at 4.

Several states also permit victims to appear and inake statements at parole eligibility liearings. See E. Villmoare \& V. NeTO, supra, at 68-71.

For a representative state statute regarding allocution, see MicH. COMP. LAws ANN. $\$ 780.765$ (Supp. 1988).

50. See Comment, Victim Impact Statement, 10 WESTERN ST. U.L. REv. 221, 226 (1983) (autliored by Martha Hoffman) (noting the potential application of the fifth and sixth amendinents to victim impact stateinents).

51. Several Suprene Court cases paved the way for the admissibility of victim impact statements by loolding that reliable unsworn or out-of-court statements could be admitted at sentencing. See, e.g., Williams v. New York, 337 U.S. 241, 251 (1949) (holding that use of a probation report at sentencing was constitutional despite the defendant's inability to examine 
The United States Supreme Court cast doubt on the constitutionality of victim impact statements, however, in Booth v. Maryland, ${ }^{52}$ a 1987 decision which held that victim impact statements are constitutionally inadmissible in capital sentencing decisions. A Maryland jury had convicted the defendant, John Booth, of two counts of first degree murder for killing an elderly couple during a robbery of their home. The jury also heard the penalty phase of the trial, and imposed one death sentence and one sentence of life imprisonment for the two inurders. ${ }^{53}$

The defendant appealed. One ground for appeal involved Article 41 , section 4-609(c) of the Maryland Code, ${ }^{54}$ which required the preparation and consideration of victim impact statements in capital cases. The defendant contended that the admission of the victim impact statements in his case violated the eighth amendment by introducing an arbitrary elenient into the sentencing decision..$^{55}$

The victim impact statements considered by the Booth jury were unusually articulate and emotional expressions of the grief and tranma the victims' children experienced after their parents were killed. The son described in haimting detail his discovery of his parents' bodies. ${ }^{56}$ The daughter told of her grief as she cleaned her parents' home to eliminate all traces of their brutal nuurder. ${ }^{57}$ Finally, the granddaughter of the murdered couple described the grief she felt at her wedding, which took place two days after the nuurders. ${ }^{58}$

The Maryland Court of Appeals rejected the defendant's argument and held that the admission of these victim impact stateinents was not unconstitutional error. ${ }^{59}$ The court held that adimssion of a victim impact statement at a capital sentencing proceeding was not per se unconstitutional because moral outrage is a permissible consideration in deciding to impose the death penalty. The court further held that the statements had not injected arbitrary considerations into the sentencing decision, but were "relatively straightforward and factual description[s] of the effects of these murders on niembers of the . . f family." 60

In a 5-4 decision, the Suprenie Court vacated the death sentence. ${ }^{61}$ The Court held that information contained in a victim inpact statement

adverse witnesses or rebut the statements). The reasoning in Williams was reaffirmed in Williams v. Oklahoma, 358 U.S. 576 (1959), and Speclit v. Patterson, 386 U.S. 605 (1967).

52. 107 S. Ct. 2529 (1987).

53. Id. at 2532.

54. MD. ANN. CODE art. 41, § 4609(c) (1982 \& Supp. 1987).

55. Booth, $107 \mathrm{~S}$. Ct. at 2532 .

56. Id. at $2537-38$.

57. Id. at 2538 .

58. Id. at 2537-38.

59. Booth v. State, 306 Md. 172, 223, 507 A.2d 1098, 1124, cert. granted, 479 U.S. 882 (1986).

60. Id.

61. Bootl v. Maryland, 107 S. Ct. 2529, 2536 (1987). 
"is irrelevant to a capital sentencing decision, and that its admission creates a constitutionally unacceptable risk that the jury may impose the death penalty in an arbitrary and capricious manner."62 The Court stated that the factors relevant to a sentencing decision are those that have "some bearing on the defendant's 'personal responsibility and moral guilt," "63 not the personal characteristics of the victims, the emotional impact of the crime on the family, or the family's opinions and characterizations of the crime and the defendant. ${ }^{64}$ Noting that not all victims have families who are able to express their sorrow as eloquently as the family in Booth, the Court reasoned that the death penalty decision should not depend on one's ability to articulate grief. ${ }^{65}$ The Court also found itself "troubled by the iniplication that defendants whose victims were assets to their community are more deserving of punishment than those whose victims are perceived to be less worthy."

The Booth Court carefully limited its holding to capital sentencing decisions, suggesting in a footnote that victim impact information inight be relevant in a noncapital criminal trial. ${ }^{67}$ Justice White, dissenting, questioned this distinction, stating that "if punishment can be enhanced in non-capital cases on the basis of the harm caused, irrespective of the offender's specific intention to cause such harm, I fail to see why the same approach is unconstitutional in death cases." 68 Nonetheless, after Booth, the constitutional validity of victim inipact statenents remains in doubt even in noncapital cases. ${ }^{69}$

62. Id. at 2533.

63. Id. (quoting Enmund v. Florida, 458 U.S. 782, 801 (1982)). In dissent, Justice Scalia poimted out that the degree of harm caused by a defendant, although wholly unrelated to blameworthiness, has generally been held by the Court to be related to that defendant's personal responsibility for the crime. As an example he noted that a robber who aims a gun at a guard and kills him may receive the death penalty, while that same robber may escape a death sentence if the gun misfires. $107 \mathrm{~S}$. Ct. at 2541 (Scalia, J., dissenting).

64. Id. at 2533-34.

65. Id. at 2534.

66. Id. at $2534 \mathrm{n} .8$. In dissent, Justice White noted that the Court already bases capital sentencing decisious on the characteristics of victims, simce one who murders the President, Vice President, a Congressman, a cabinet official, or a Supreme Court justice may receive the death penalty, whether or not the victim's identity is known to the assassim. Id. at 2540 n.2.

67. Id. at 2535 n. 10 .

68. Id. at 2540 (footnote omitted) (White, J., dissenting).

69. The Booth Court may have strained to distinguish capital sentencing because it wished to preserve the notion of victim involvement in some capacity. In recent years, the Court has shown an increasing tendency to recognize the crime victim in its decisions. See generally O'Neill, The Good, the Bad, and the Burger Court: Victims' Rights and a New Model of Criminal Review, 75 J. CRIM. L. \& CRIMINOLOGY 363 (1984); Pauley, The Emerging 'Victim Factor' in the Supreme Court's Criminal Jurisprudence, 61 IND. L.J. 149 (1986).

Since Booth was decided, some lower courts have permitted the admission of victim impact statements in noncapital cases. See Tïbss v. State, 72 Md. App. 239, 258 n.6, 259, 528 A.2d 510, 519 


\section{Posttrial Reform: Practical Limitations}

In addition to the constitutional concerns imphicated by the use of victim impact statements, the statements simply have not hived up to their imitial promise as a means of empowering victims. First, victim impact statements are admissible only after a defendant has been convicted at trial. Since over ninety percent of all criminal cases end in a negotiated guilty plea and no trial is ever held, ${ }^{70}$ most victims never have the opportunity to present a statenient.

In addition, very few impact statements are actually considered at sentencing. A Maryland study revealed that, over a six-month period, only twenty-three percent of presentence reports in that state contained a victim impact statement. ${ }^{71}$ This may be traced to inadequate victim notification procedures, which proved to be the major obstacle to the implenientation of allocution in Califorina. ${ }^{72}$ A Califorina study found that, even though the increase in workload caused by the notification process was minimal, ${ }^{73}$ less than half of the victims sampled were aware of their allocution right. ${ }^{74}$ The study further estimated that less than three percent of the eligible victims actually appeared at sentencing hearings. ${ }^{75}$ While an Ohio study reported higher victim participation, stating that nearly sixty percent of sexual assault victims made a sentencinig recom-

n.6, cert. denied, 311 Md. 286, 533 A.2d 1308 (1987); Killebrew v. Texas, 746 S.W.2d 245, 247.48 (Tex. Ct. App. 1987).

In addition, some courts have limited Booth to its particular facts, holding that victim impact statements may be considered by a judge, but should not be presented to a jury. See Lightbourne v. Dugger, 829 F.2d 1012, 1027 \& n.16 (11th Cir. 1987), cert. denied, 109 S. Ct. 329 (1988); State v. Bell, 293 S.C. 391, 402-03, 360 S.E.2d 706, 712-13 (1987), cert. denied, 108 S. Ct. 734 (1988). But see Patterson v. State, 513 So. 2d 1257, 1263 (Fla. 1987) (holding that a victim impact statement heard by the judge alone constituted reversible error in light of Booth).

Finally, several courts have evaded the Booth reasoning entirely, by holding that challenged statements do not rise to the level of the statement at issue im Booth, and therefore do not pose the danger of an arbitrary sentencing decision. See Hill v. Thigpen, 667 F. Supp. 314,338 \& n.4 (N.D. Miss. 1987); People v. Ghent, 43 Cal. 3d 739, 771-72, 739 P.2d 1250, 1271-72, 239 Cal. Rptr. 82, 103-04 (1987), cert. denied, 108 S. Ct. 1099 (1988); Mills v. State, 310 Md. 33, 72-73 \& n.14, 527 A.2d 3, 22 \& n.14, cert. granted, 108 S. Ct. 484 (1987), vacated, 108 S. Ct. 1860 (1988); State v. Brown, 320 N.C. 179, 202-03, 358 S.E.2d 1, 17-18, cert. denied, 108 S. Ct. 467 (1987).

70. R. Elias, supra note 5, at 150; J. KAPLAN \& J. Skolnick, Criminal Justice 454 (9th ed. 1987) (quoting from an address by Chief Justice Warren Burger, N. Y. Times, Aug. 11, 1970, at 24, col. 4); Cramer, Rossman \& McDonald, The Judicial Role in Plea-Bargaining, in PLEABargaining 139 (W. McDonald \& J. Cramer eds. 1980).

71. See Hudson, The Crime Victim and the Criminal Justice System: Time for a Change, 11 PePperdine L. ReV. 23, 53 (1984).

72. E. VillmoARE \& V. NeTO, supra note 49 , at ix. 1n California, forn notices are mailed to victims by the probation department, informing them of their right to make an oral or written impact statement. Id. at 32. The problem, however, is that the probation departments do not view themselves as responsible for conducting follow-up on the notification. Id. at 34 .

73. Id. at 57. The estimated additional time it takes a probation department official to prepare the victim impact statement is approximately one hour per case. Comment, supra note 50, at 225 .

74. E. VILlMOARE \& V. NETo, supra note 49 , at 42.

75. Id. at 52 . 
mendation in the presentence report, the study also noted the paucity of available participation statistics. ${ }^{76}$ Inadequate notification procedures therefore appear to be a major factor limitimg the effectiveness of victim impact statements.

Even when victims do participate by making a statement, judges often disregard it when making sentencing decisions. In states where both the right to make a written statement and the right to allocute coexist, many judges feel that allocution is superfluous. ${ }^{77}$ Further, judges in states that have determinate sentencing laws are significantly constrained by those sentencing codes and may be unable to adjust their sentence to reflect victim impact. ${ }^{78}$ Finally, some judges simply feel that they receive adequate information about the victim without the victim impact stateinent. ${ }^{79}$ In fact, one study characterized the victim impact statement as "a mere genuflection to ritualistic legalism" that simply creates the impression that "something is being done." 80

In hight of the holding in Booth, the future admissibility of victim impact stateinents is unclear. As the Court noted, the involvement of a crime victim in the sentencing phase of a capital criminal trial raises serious constitutional concerns. In addition, the statements of victims have been only minimally effective im enhancing victim impact, due in large part to the vast number of cases that are disposed of before trial, low victim participation in making the statements, and the minimal effect of such stateinents when made. Some researchers have concluded that "[i]f the intent . . . is to give victims an opportumity to comment on and influence the sentences for the crimes committed against thein, victim participation must exist at earier stages in the prosecution of cases." Accordingly, several jurisdictions have atteinpted to provide for meaningful participation by victims at the pretrial stage of the criminal process.

\section{B. Reforms at the Pretrial Stage}

By far the overwhelming majority of criminal defendants never undergo a criminal trial because they enter a negotiated guilty plea. ${ }^{82}$

76. Walsh, Placebo Justice: Victim Recommendations and Offender Sentences in Sexual Assault Cases, 77 J. CRIM. L. \& CRIMnology 1126, 1130 (1986).

77. One study reported that two-thirds of the judges surveyed saw no need for allocution, since the victim impact statement in the presentence report provided all the information necessary to inake a sentencing decision. E. VILLMOARE \& V. NETo, supra note 49, at 37.

78. See id. at 59, 62 (stating that plea bargaining and Califorma's determinate sentencing law together severely limit the possible impact of victim allocution on sentencing results).

79. See J. Hernon \& B. Forst, The Criminal Justice Response to Victim HaRm 59 (1984).

80. Walsh, supra note 76 , at 1139.

81. E. VIILMOARE \& V. Neto, supra note 49, at 62.

82. See supra note 70 and accompanying text. 
The process of obtaining guilty pleas is known as plea bargaining.

In the plea bargaining process, "the defendant relinquishes [the] right to go to trial in exchange for a reduction in charge and/or sentence." 83 The judge maintains a nonparticipatory, supervisory role in the process and is not bound by any sentencing agreeinent the parties reach. In practice, however, judges usually accept these recommendations. ${ }^{84}$ Many legal observers consider the current system of plea bargaining to be a necessity in an overburdened and underbudgeted criminal justice systein. ${ }^{85}$

The plea bargaining process, however, has been characterized by an "almost total disregard for the role of the victim."86 Plea negotiations typically involve only the prosecutor and the defense counsel; victims are neither notified nor allowed to participate. Consequently, a few attempts at victim-oriented reform have attempted to bring the victim into the pretrial plea bargaining process. Some jurisdictions now allow crime victims to attend pretrial negotiation conferences and to give their opinions regarding disposition agreeinents. The scope of these reforms has been limited, however, as victims are not permitted to have a voice in the ultimate disposition decision.

\section{Pretrial Reform: A Legal Analysis}

Crime victim participation in pretrial negotiations may be challenged as interfering with the presumption of iunocence that characterizes our systein of criminal justice. An accused suspect is presumed innocent until tried and found guilty of a crime. In order to prove guilt, the state must estabhish, ainong other things, that a crime was in fact committed and that the accused suspect was responsible. Thus, a victim is actually only a "presumed" victim of any particular defendant at the pretrial stage of the hitigation. ${ }^{87}$ Involvement of an "alleged" victim at this stage arguably is inappropriate, since it has not yet been established (1975).

83. Heumann, A Note on Plea Bargaining and Case Pressure, 9 LAw \& Soc'Y Rev. 515, 515

84. See Cramer, Rossman \& McDonald, supra note 70, at $144-45$ (approximately two-thirds of judges follow to some extent prosecutors' sentencing recommendations).

An interesting case in which a victim played a role in a state appeals court judge's refusal to honor a plea bargain occurred recently in California. In that case, the judge at a sentencing hearing permitted a member of the deceased victim's family to inake a statement regarding the inpropriety of accepting a plea bargain in the case. The victim's relative urged that the judge reject the plea bargain proposed by the defendant and the prosecutor, because it had been obtained as a result of favoritism. (Several inembers of the defendant's family worked for the local police and probation departinents.) The judge concurred, and refused to honor the plea. People v. Stringham, $306 \mathrm{Cal}$. App. 3d 184, 253 Cal. Rptr. 484 (1988).

85. J. KAPLAN \& J. SKolNicK, supra note 70 , at 455.

86. Hall, The Role of the Victim in the Prosecution and Disposition of a Criminal Case, in Perspectives on Crime Victims 331 (B. Galaway \& J. Hudson eds. 1981).

87. R. Elias, supra note 5, at 139; E. ZIEGENHAGEN, supra note 12, at 146. 
as a matter of law that this particular victim has been harmed by the accused. ${ }^{88}$ Yet this argument does not withstand close scrutimy.

First, involvement of an "alleged" victim at the pretrial stage does not affect the ultimate determination of a defendant's guilt or innocence. Whether or not a victim participates in pretrial negotiations, the defendant is never required to plead guilty, and retains the option of proceeding to trial for a determination of guilt. ${ }^{89}$

Yet the imvolvement of a sympathetic victim im pretrial negotiations might be seen as placimg unduly coercive pressure on a presumably innocent defendant. The concern is that a defendant, faced with an "alleged" victim who has suffered obvious harm and who vocally seeks retribution, may be pressured into pleading guilty before it is ever legally determined that the harm done to that victim was caused by the defendant charged with the crime. Arguably, it is unfair for an "alleged" victim, who might not have been harmed by the defendant charged, to subject that defendant to such pressure.

Yet current plea bargaining practice, which does not involve the victim, already forces the "presumed" offender to choose between a fairly certaim "bargained" sentence and an uncertain but potentially harsher sentence in the event of a guilty verdict at trial, before presentimg a shred of evidence to a court. The Supreme Court has rejected the argument that it is somehow improper to subject "presumed" offenders to this inherently coercive pressure, holding instead that, within certain broad limits, the constitutionality of plea bargaining is beyond challenge. ${ }^{90}$ Existing due process requirements sufficiently protect defendants from undue coercion. The "presumed" offender is under no legal obhigation to aceept any charge or sentence decision the prosecutor offers. ${ }^{91}$ A defend-

88. Note that this concern with the legal status of crime victims would not preclude victim assistance programs and other satisfaction-oriented reforms, but would prohibit any effective impact by crime victims before trial on criminal charging or sentencing.

89. See, eg., J. KAPLAN \& J. SKOLNICK, supra note 70, at 461 (recounting two cases in which defendants rejected generous offers by the prosecution that resulted in significantly harsher sentences following trial); Kipnis, Criminal Justice and the Negotiated Plea, in F. ZIMRING AND R. FRASE, supra note 21 , at 520 ("[A] defendant can always reject any offer of concessions and challenge the state to prove its case.").

It is clear, however, that criminal defendants generally feel they possess minimal bargaining power in the negotiation process, particularly when they are in custody while awaiting trial. See J. KAPLAN \& J. SKOLNICK, supra note 70, at 476-79.

90. See Santobello v. New York, 404 U.S. 257, 262 (1971), in which the Court approved of the plea bargaining process as long as plea agreements are kept; see also Halberstam, Towards Neutral Principles in the Administration of Criminal Justice: $A$ Critique of Supreme Court Decisions Sanctioning the Plea Bargaining Process, 73 J. CRIM. L. \& CRIMINologY 1, 2-3 (1982) ("[T]he Supreme Court has rejected challenges to the constitutionality of this process in every case that has come before it.") (footnote ourtted).

91. See supra note 89 and accompanying text. 
ant's plea of guilty must be voluntary and is invalid if coerced. ${ }^{92}$ Additionally, the judge inay not determine the voluntariness and intelligence of a waiver of the right to trial by the defendant's silence, but inust establisli these elements through explicit inquiries. ${ }^{93}$ Finally, there must be a factual basis for the plea. ${ }^{94}$

These constitutional constraints shield the defendant from prosecutorial coercion during plea negotiations. Clearly, the saine protections would also apply to a bargaining process that included a victim. In fact, the pretrial negotiation phase provides a unique opportunity to increase victim involveinent without threatening a defendant's constitutional protection. The defendant is always free to either accept an offer approved by the victim or to reject it and proceed to trial. The involvement of the victim at this stage therefore does not alter the delicate balance of government and defendant interests that lias been established and protected by the due process clause.

\section{Pretrial Reform: Practical Limitations}

A liandful of jurisdictions have implentented a policy of including crime victims in pretrial plea negotiations. The inost coinpreliensive study of this type of prograin took place im Dade County, Florida. ${ }^{95}$ In the Florida prograin, victims were invited to attend structured plea negotiation conferences. The defendant, defense counsel, the prosecutor, the police officer, and the judge were also present. During these informal conferences, the attorneys discussed the proposed disposition of the case with the judge. The judge then questioned the victims regarding the losses or mjuries they had sustained, and imquired whether tliey were satisfied with the proposed disposition. The victims, lowever, were not perimitted to veto any proposed settlement. ${ }^{96}$

Participation by victims in structured plea bargaining conferences, like participation througli victim impact stateinents, lias been low. The

92. Scattered Supreme Court cases since 1926 have held that a negotiated guilty plea must be voluntary and uncoerced. See, e.g., McCarthy v. Umited States, 394 U.S. 459, 465 (1969); Boykin v. Alabama, 395 U.S. 238, 242 (1969); see also FED. R. CRIM. P. 11(d); A. ROSETT \& D. CRESSEY, JUSTICE BY CONSENT 58 (1976). The Court has also held that statutes which provide harsher punishments for defendants who insist on proceeding to trial are invalid. Id. at 64 .

However, a guilty plea is not involuntary because it is made in order to avoid the possible imposition of the maximum legal penalty following a guilty verdict. Brady v. Umited States, 397 U.S. 742, 755 (1970); Parker v. North Carolina, 397 U.S. 790, 795 (1970). The Court has held fast to this position even when such a plea is made by a defendant who simultaneously claims innocence. See North Carolina v. Alford, 400 U.S. 25, 37 (1970).

93. Boykin v. Alabama, 395 U.S. 238, 242-43 (1969); FED. R. CRIM. P. 11(d).

94. See FED. R. CRIM. P. 11(f).

95. See Heinz \& Kerstetter, Victim Participation in Plea-Bargaining: A Field Experiment, in Plea-BARgaining, supra note 70, at 167-73. Similar programs have been attempted in Detroit, Louisville, and Clearwater. See E. VILlmoARE \& V. NETo, supra note 49, at 6.

96. Heinz \& Kerstetter, supra note 95, at 167. 
Florida study reported that only approximately one-third of all victims actually participated in structured plea negotiations. ${ }^{97}$ Again, one reason for the low participation rate appeared to be inadequate victim notification. ${ }^{98}$

When victims did participate, however, they did not create delays in case processing or agitate for harsher sentences as critics had expected. ${ }^{99}$ In fact, the average length of the pretrial settlennent conferences in the Florida study was only ten minutes. ${ }^{100}$ In addition, the researchers reported that victims consistently agreed with the disposition proposed by the attorneys. ${ }^{101}$ The Florida research team concluded that "the effect on sentencing, if any, was toward a reduction in sentence severity and use of incarceration." 102

The Florida researchers suggested, however, that victims under these circumstances inay agree with proposed settleinents out of a sense of intimidation and a reluctance to disturb an apparent concurrence of professional opinion. ${ }^{103}$ In addition, the victims may have been acutely aware that they had no actual power to inodify an unsatisfactory disposition, although it is unclear to what extent this affected their decisions. ${ }^{104}$ Nevertheless, the attorneys and judges were certainly aware of the victims' lack of actual power and inay have subliminally signalled to thein that the disposition decision was not subject to change. This too inay explain the failure of these programs to deinonstrate any significant effect on actual sentencing decisions. ${ }^{105}$

Overall, the reform attempted in Florida was only inarginally

97. Id. at 169; see also T. Weigend, Assisting THE Victim 62 (1981). But see $\mathrm{E}$. VILLMOARE \& V. NETO, supra note 49, at 6 (claiming over 50\% participation overall by eligible victims in Dade County, Detroit, Louisville, and Clearwater).

98. Heinz \& Kerstetter, supra note 95, at 169. There did not appear to be a relationship between nonattendance and any particular victim characteristics, such as age, sex, or occupation. Id. at $169-70$.

99. Id. at $174 \&$ n. 15 .

100. Id. at 170; see also E. VillmoARE \& V. NeTo, supra note 49, at 6 (victim participation consumed less than $10 \%$ of the total speaking time).

101. See Heinz \& Kerstetter, supra note 95, at 172; see also T. WEIGEND, supra note 97, at 62.

102. Heinz \& Kerstetter, supra note 95, at 174.

103. Id. at 172 .

104. It appears that the victims in some of these experimental programs liad at least a limited awareness of their lack of actual decisionmaking power. See E. VILLMOARE \& V. NETO, supra note 49 , at 6 (noting that the majority of participating victims did not believe their presence affected the outcome of the conference).

105. It is also possible that these victims merely deferred to the attorneys' proposed dispositions out of a sense that lawyers have superior competence and expertise with respect to criminal sentencing. While it is impossible to determine whether victims acquiesced out of deferential respect or out of recognition of their own impotence, it is clear that acquiescence out of impotence umdercuts the rationale for permitting victim imvolvement in the first placc. A reform meclianism must therefore guard againist the possibility of this form of acquiescence. A procedure that empowers victims, sucl as the one this Comment proposes, cures this potential defect. 
successful. Involving the victim in the pretrial negotiation process did appear to increase victims' knowledge of the status of their cases. Although victims who participated in the conferences were soinewhat more satisfied with the criminal justice process than nonparticipating victims, this difference was not statistically significant. ${ }^{106}$ One commentator who studied the Florida conferences felt that they gave the victim "the feeling that he is taken seriously as a participant in the criminal process, that decisions in 'his' case are not unade in secret dehberations but with his participation." 107 Given the anecdotal nature of these results, however, it is difficult to draw conclusions as to whether the imvolveinent of victims in pretrial negotiations increased victim satisfaction to any significant degree.

Perhaps the most mteresting outcome of the Florida experiment was the high level of victim agreement with the disposition decision. It is certainly possible that most of the victims who participated in the conferences actually agreed that the prosecutor's plea offer represented a fair disposition of the case. Yet such a conclusion is preinature. The victims simply may have felt they lacked the authority to alter the disposition. At best, victims could only hope to influence indirectly the disposition decision, ${ }^{108}$ since the nltimate power to accept or reject the disposition offer rested with the defense, regardless of the victims' feelings. Consequently, it is likely that these victims felt powerless to influence a decision that appeared to have been made already.

To be counpletely certain that victim acquiescence actually represents victim agreement, it is necessary that victim involvement take place before the prosecutor conveys an offer to the defense. Involving the victim first avoids giving the victim the impression that the prosecutor is merely notifying the victim of the offer before passing it on to the defense counsel, who will accept or reject it regardless of the victim's objection.

\section{Pretrial Reforms: Summary}

This section has argued that the pretrial negotiation stage provides a unique opportunity for effective victim impact on criminal dispositions while preventimg infringement of the defendant's constitutional rights.

106. Victims who attended pretrial settlement conferences in Florida were much morc likely to feel informed of their case disposition than those who did not attend such a conference. However, the attendees in the Florida study were not significantly more satisfied than absentees or the control group with the process or the disposition. Heinz \& Kerstetter, supra note 95, at 173-74. The results of the other pretrial victim involvement programs are difficult to compare with the Florida experiment, since their analyses were not statistical. See E. VILlMOARE \& V. NETO, supra note 49, at 6 (victims who participated in Detroit, Louisville, and Clearwater studies were more satisfied with the outcome and with plea bargaining in general than those who did not participate).

107. T. WEIGEND, supra note 97 , at 63.

108. One review of the Florida study suggests that the victim's opposition may have made a difference in borderline cases. T. WEIGEND, supra note 97, at 62. 
However, reform efforts aimed at this stage to date have been relatively rare, and have consisted of permitting victims to attend pretrial negotiation conferences without granting them a voice in the outcome of those conferences. Although the inclusion of victims in pretrial negotiations shows promise as a means of increasing victim satisfaction, studies of pilot programs have failed to convincingly demonstrate this effect. Further, because none of the programs studied actually empowered the victim, it is difficult to determine what effect victim impotence had on reported levels of satisfaction with the process.

The proposal that follows picks up where prior pretrial reform efforts have left off. It gives victims the opportunity to have an actual impact on the pretrial disposition of their criminal cases. It attempts to avoid the shortcomings of other pretrial victim participation programs by involving the victim before defense counsel is consulted, and by giving the victim actual, rather than illusory, power to influence the disposition decision.

\section{III}

\section{EmPowering the Victim: A Proposal}

For victims to have an effective voice in the disposition of criminal cases, they must have an opportunity to participate at the pretrial stage, when the majority of disposition decisions are inade. Actual empowerment of victims at this stage has the potential to significantly imcrease victim satisfaction. It is likely that this mcreased satisfaction would, in turn, improve victim reporting rates and overall participation by victims in the system. ${ }^{109}$

\section{A. The Proposal}

Prosecutors' offices should establish, as a matter of department policy, a binding crime victim's veto exercisable over prosecutorial disposition offers made before trial. ${ }^{110}$ The proposed pohicy would require prosecutors to disclose any disposition offers to the crime victim before communicating them to the defense. ${ }^{111}$ The prosecutor would explain both the proposed disposition and its underlying rationale.

109. An increase in victim satisfaction can be expected to have a multiplier effect. Members of the victin's family and community are likely to approve of the responsiveness the criminal justice system has slown the victim by granting that victim the opportunity to have an impact on the disposition of the case. Their impression of the criminal justice system as responsive to victims' needs will increase the likelihood that they, too, will report crimes and vigoronsly pursue the prosecution of suspects in the future.

110. Becanse this proposal recommends a policy to be adopted by district attorney's offices, rather than a legislative inandate to be inposed upon them, it does not implicate separation of powers concerns.

111. Iu cases of homicide, a representative of the victim's immediate family would be consulted. 
The victim, after reviewing the offer and the underlying prosecutorial justification, would be asked to sign a release form that would permit the prosecutor to present the offer to the defense. Victims who find the offer too punitive or too lenient could refuse to give their consent and thereby exercise a veto. When this occurred, the prosecutor would be required to formulate another offer and present it to the victim. This process would continue until the victim and the prosecutor reached agreeinent on the terms of the disposition offer. If the victim and the prosecutor failed to agree on an offer within the time allotted by the apphicable speedy trial statutes, the case would proceed to trial.

Ideally, the disclosure procedure should minimize the investment of prosecutorial time while fully notifying victims of their right to exercise a veto. The following procedure suggests a ineans of effective and efficient implementation.

Victims would receive written notification of the prosecutor's intent to inake a disposition offer. ${ }^{112}$ The notification would contain a brief explanation of the charges, as well as a description of the statutory range of sentencing options and incarceration alternatives (work furloughs, drug diversion programs, and so on) for which the defendant is eligible. ${ }^{113}$ The notification would also inform victims of their right to contact the district attorney for an explanation of the proposed disposition, and of their ultimate right to veto the offer should they find it excessively lenient or harsh. Finally, the notification would state the number of days within which the victim inust respond to preserve the veto privilege. The burden of follow-through would rest entirely with the victim. If a victim failed to respond within the allotted time, the offer would become active and the prosecutor could cominunicate it to the defense.

Certainly, this proposal will draw some substantive criticisms. The following section addresses these anticipated objections.

\section{B. A Critical Evaluation of the Proposed Victim's Veto}

The criticisms that may be levelled at the victim's veto can be grouped into three broad categories: (1) It is unconstitutional; (2) it would not advance its purported public policy goals; and (3) it is not feasible given the existing constraints on an already overburdened

112. Representatives from victim/witness assistance programs or the probation department could initially assume the responsibility for victim notification.

113. Presenting a range of options to the victim is injportant if one is concerned about dampeumg victims' potential tendencies toward punitiveness. One study has shown that "victims are quite willing to nove away from a position of retribution if given viable alternatives." Henderson \& Gitchoff, Using Experts and Victims in the Sentencing Process, 17 Crim. L. BuLL. 226, 230 (1981). 
criminal justice system. The following discussion considers each of these criticisms.

\section{Constitutional Analysis of the Proposal}

Opponents of mcreased victim impact on criminal sentencing decisions may object to this proposal on both due process and equal protection grounds. First, the proposal may evoke concern that failure of the victim and the prosecutor to reach agreement regarding a plea will effectively deny due process to some criminal defendants by eliminatimg their opportunity to plea bargain. A second potential concern is that the proposal will allocate scarce criminal justice resources to certain classes of defendants im ways that violate equal protection. Specifically, defendants accused of committing "victimless" crimes (such as drug offenses) would continue to enjoy unrestricted access to plea bargaining, while those defendants accused of committing crimes mvolving victims may suffer reduced access to the plea bargaining process. Further, even in those cases where the veto theoretically apphes, some offenders will bargain freely because the victim elects not to veto the prosecutor's offer, while others will have restricted access to the bargaining process because of a victim's veto. The proposal thus clearly implicates both due process and equal protection concerns.

\section{a. Due Process and Plea Bargaining}

The constitutional right to due process of law guarantees that any sanction that deprives a defendant of life, hiberty, or property inust "be implemented in a fair manner." 114 Yet, under the terms of this proposal, soine defendants may not receive a plea offer at all. Although depriving a defendant of the opportunity to plea bargain may seem unfair, the Supreine Court has held that a criminal defendant has no constitutional right to a plea bargain. In Weatherford $v$. Bursey, ${ }^{115}$ the Court dismissed the notion of a constitutional right to plea bargain, saying: "It is a novel arguinent that constitutional rights are infrimged by trymg the defendant rather than accepting his plea of guilty."116 In fact, several jurisdictions have taken steps to eliminate plea bargaining altogether. ${ }^{117}$

114. United States v. Salerno, 107 S. Ct. 2095, 2101 (1987).

115. 429 U.S. 545 (1977).

116. Id. at 561 .

117. These attempts have met with varying degrees of success. See, e.g., C. McCoY \& R. Tillman, Controling felony Plea Bargaining in California: The Impact of the “VicTIMs' Bill OF RIGHTS" 4 (1986) (California ban on plea bargaining in superior courts merely shifted plea negotiations to earlier stages in the process); Church, Plea Bargains, Concessions and the Courts: Analysis of a Quasi-Experiment, 10 LAw \& Soc'y REv. 377, 379-83 (1976) (district attorney's policy prohibiting plea bargaining with drug dealers caused trial rate to soar and total number of guilty pleas to decrease considerably, although guilty pleas to original cliarges increased dramatically); Rubinstein \& White, Alaska's Ban on Plea Bargaining, 13 LAW \& Soc'Y REv. 367, 
The more compelling constitutional concern with the proposed victim's veto is whether it unfairly infringes on the constitutional rights of certam classes of criminal defendants. The classifications that result from the exercise of a victim's veto must withstand equal protection scrutimy.

\section{b. Equal Protection Analysis}

The fifth and fourteenth amendments to the Constitution guarantee to all citizens the equal protection of the laws. ${ }^{118}$ Under the terms of this proposal, criminal defendants who have committed the same offense in the same jurisdiction may receive different treatment, depending on whether the crime victim chooses to exercise a veto. Under current equal protection analysis, however, this differential treatment easily withstands constitutional scrutiny.

As a preliminary matter, it is important to note that under current plea bargaining practices, criminal defendants accused of the same offense commonly enjoy differing degrees of access to the negotiation process, and this variation in access frequently produces different outcomes. In some jurisdictions, for example, the defendant must initiate plea negotiations. As a result, a naive or uninforıned defendant who fails to make the proper overtures to the prosecution may unwittingly proceed to trial and receive a sentence that is "grossly inconsistent with the customary practices of the jurisdiction." 119

Although the Supreme Court has not addressed the issue, lower federal courts have held that differing treatment of defendants accused of committing the same crime is a constitutional exercise of prosecutorial discretion. These courts have held that prosecutors have discretion to file different charges against individuals who have committed the same offense. ${ }^{120}$ This commonly occurs when a district attorney offers one

378-80 (1979) (most defendants continued to plead guilty im absence of explicit sentence bargaining); Weninger, The Abolition of Plea Bargaining: A Case Study of El Paso County, Texas, 35 U.C.L.A. L. REV. 265, 293 (1987) (elimination of plea bargaining resulted in doubling of trial rate); Note, The Elimination of Plea Bargaining in Black Hawk County: A Case Study, 60 IowA L. Rev. 1053, 106669 (1975) (elimination of plea bargaining in Black Hawk County, Iowa resulted in a significant decrease in the three inajor forms of plea bargaining and markedly increased efficiency of the criminal justice system); see generally Parnas \& Atkins, Abolishing Plea Bargaining: A Proposal, 14 CrIM. L. BuLL. 101, 109-14 (1978) (reviewing attempts in four jurisdictions to eliminate plea bargaining).

118. U.S. ConsT. annend. V; id. amend. XIV, § 1.

119. D. Newman, Conviction: The Determination of Gullt or InNocence Without TRIAL 42 (1960).

120. Newman v. United States, 382 F.2d 479, $481-82$ (D.C. Cir. 1967) (to require prosecutors to treat all offenses and offenders alike would be "an impossible task," and furtlier, prosecutors are "expected to exercise discretion and common sense"); United States v. Collins, 395 F. Supp. 629, 633 (M.D. Pa. 1975). 
codefendant a plea bargain in exchange for testimony against an accomplice, who is then convicted at trial.

The victim's veto, however, presents the question whether defendants can constitutionally receive different treatınent based upon the victim's willingness to exercise a veto. Since this classification (defendants whose victims exercise a veto versus those whose victims do not) does not involve either a suspect class or a fundanental interest recognized by the Supreine Court, ${ }^{121}$ a rational basis standard of equal protection review applies. ${ }^{122}$ Therefore, the classification must "rationally further[ ] some legitimate, articulated state purpose . ..."123

The victim's veto rationally furthers the legitimate state interest in increasing victim involvement and participation in the criminal justice systein. If victims who desire to voice an opimon regarding the disposition of their criminal case are permitted to do so, and if their opimions actually affect the outcoine of the case in a direction satisfactory to thein, they are much more likely to view the criminal justice systein as responsive and effective. They are also inore likely to participate in the future, should revictimization occur. Based on this reasoning, the victim's veto satisfies the rational basis standard of equal protection review.

In fact, in many jurisdictions a victim's willingness to participate already provides a basis for the differential treatment of accused criminals. The presence or absence of victims at preliminary hearings presents a case of differing treatment of defendants closely analogous to the proposed victim's veto. In inost states, a preliminary hearing is held soon after arraignment, but before trial, to determine whether sufficient evidence exists to hold the defendant over for trial. ${ }^{124}$ If a victim-witness crucial to the prosecution's case fails to appear at the preliminary hearing, the prosecution will not be able to meet its burden of proof and the charges against the defendant must be dismissed. ${ }^{125} \mathrm{~A}$ different

121. The Supreme Court has limited the designation of suspect classifications to race and national origin. See, e.g. Hernandez v. Texas, 347 U.S. 475 (1954) (discrimination against MexicanAmericans with regard to jury service); Yick Wo v. Hopkins, 118 U.S. 356 (1886) (administrative discrimination against Chinese aliens).

The Court has recognized as fundamental the right to vote, see Harper v. Virginia Bd. of Elections, 383 U.S. 663 (1966) (invalidating a poll tax imposed as a prerequisite for voting); the rights of indigents to equal access to criminal courts, see Griffin v. Illinois, 351 U.S. 12 (1956) (holding that the state must provide indigent defendants with trial transcripts if necessary for effective appellate review); and the right to interstate travel, see Shapiro v. Thompson, 394 U.S. 618 (1969) (invalidating the denial of welfare benefits to newly arrived state residents).

122. See, e.g., San Antorro Indep. School Dist. v. Rodriguez, 411 U.S. 1, 18-44 (1973).

123. Id. at 17.

124. See J. JACOBY, supra note 10 , at $145-51$.

125. For example, the California Penal Code provides that "[i]f [at the preliminary examination] ... it appears ... that there is not sufficient cause to believe the defendant guilty of a public offense, the magistrate shall order the complamt dismissed and the defendant to be discharged ...." Cal. Penal Code $\S 871$ (West 1985). 
defendant, charged with the identical offense, will be held to answer at a preliminary hearing if all the necessary witnesses are present.

Even though the proposed victim's veto withstands due process and equal protection scrutiny, to be worthwhile it must also advance public pohicy concerns. The following section argues that reversing the trend of excluding victims froin the criminal justice process furthers several important public pohcies.

\section{Policy Issues Implicated by the Proposal \\ a. Harnessing Prosecutorial and Judicial Discretion}

Accounts of the nearly unlimited nature of prosecutorial and judicial discretion are rampant in the criminal justice hiterature. ${ }^{126}$ While many commentators criticize the substantial power of prosecutors and judges, whose decisions are subject to only minimal scrutiny, ${ }^{127}$ others recognize that soine degree of discretion is essential to the smooth functioning of the criminal justice system. ${ }^{128}$ An anticipated criticisin of this proposal is that it will upset this discretionary authority currently vested in the judiciary and the prosecution. ${ }^{129}$

Prosecutors traditionally have had free rein to decide whether to file or drop charges in any given case, which charges to file, and whether to bargain with the defendant or proceed to trial. These prosecutorial decisions are essentially unreviewable. ${ }^{130}$ For example, a citizen has no right

126. See, e.g., Atkins \& Pogrebin, Discretionary Decision-Making in the Administration of Justice, in The INvisible Justice System: Discretion AND THE LAw 6-10 (B. Atkins \& M. Pogrebin eds. 1982) [hereinafter THE INvisible JUSTICE SYSTEM] (describing prosecutorial and judicial discretion); Friedman, Discretion and Public Prosecution, in id. at 69-73 (noting the reasons for broad prosecutorial discretion and the traditionally unreviewable nature of these discretionary decisions).

127. See, eg., J. JACOBY, supra note 10, at 33-36 (reviewing the developing criticisin of unhampered prosecutorial discretion); Davis, Confining, Structuring, and Checking Prosecuting Power, in The INVISIBLE JUSTICE SySTEM, supra note 126, at 80-90 (questioning the concept of unreviewable prosecutorial discretion); Frankel, Criminai Sentences; Law Without Order, in id. at 104-13 (decrying excessive judicial discretion in sentencing).

128. See, e.g., Atkins \& Pogrebin, supra note 126, at 8 ("Judicial discretion, like . . prosecutorial discretion, is inevitable."); Rosett, Discretion, Severity and Legality in Criminal Justice, in The INVIS1BLE JUSTICE SYSTEM, supra note 126, at 19-20 (discussing the inevitability of discretion).

129. Decisions to charge and prosecute are traditionally reserved to the executive branch of government, of which the district attorney's office is a part. See United States v. Nixon, 418 U.S. 683, 693 (1974) ("[T] Executive Branch has exclusive authority and absolute discretion to decide whether to prosecute a case."). Sentencing, on the other hand, is within the purview of the legislative and judicial branches. Criminal definitions and sentencing guidelines are established by state legislatures. The judiciary is then given broad discretion to impose sentences, withni these legislatively-determined limits. See Y. KAMISAR, W. LAFAVE \& J. ISRAEL, MODERN CRIMINAL Procedure 14 (6th ed. 1986); N. KitTrie \& E. Zenoff, Sanctions, Sentencing, and CORRECTIONS 58-64, 75-92 (1981).

130. See P. Dow, Discretionary Justice: A CRITICAL INQuiRY 99 (1981) (the district attorney's decision is "virtually unalterable and unreviewable" by other parties in the legal system 
to appeal a prosecutor's decision not to prosecute a case. ${ }^{131}$

The proposed victim's veto does not interfere with prosecutorial discretion to charge or prosecute the offender, because the veto can only be exercised after criminal charges have been filed. Moreover, prosecutorial filing of charges indicates the district attorney's willingness to proceed to trial if no pretrial settlement is reached. The veto therefore does not force prosecution; rather the district attorney has already indicated a willingness to prosecute by charging the defendant with a crime.

Requiring prosecutors to abide by a victim's veto will certainly impair prosecutorial bargaining discretion to some degree. And yet, given that prosecutors are currently coinpletely unhampered by any pubhic scrutiny of their discretionary charging and bargaining decisions, some limitations on this discretion are not necessarily inappropriate. This seems particnlarly true when one considers that inany of the decisions prosecutors make do not necessarily reflect the public interest, but rather stem from considerations such as a desire to win an upcoming election or a perceived need to maintain a high conviction rate. ${ }^{132}$

The Supreine Court has stated that prosecutors may consider "a wide range of factors" in determining whether prosecution of a case is "in the public interest." 133 By imphication, there is no reason that a prosecutor should not be required to consider the public interest in deciding whether to offer a plea bargain. Although the public interest is amorphous and difficult to define, the recent growth of the Victims' Rights Movement suggests that victim satisfaction is a relevant consideration. The existence of a victim's veto, even if rarely exercised, provides for inomitoring of prosecutorial discretion by those inembers of the general public most affected by crime-its victims.

Moreover, although the victim's veto may result in soine impairment of prosecutorial discretion, arguably a legitimate and positive

and outside third parties); id. at 122 (legal accountability for prosecutorial misconduct is "negligible").

131. See Linda R.S. v. Richard D., 410 U.S. 614, 619 (1973) (noting that "a citizen lacks standing to contest the policies of the prosecuting authority when he himself is neither prosecuted nor threatened with prosecution" and that "a private citizen lacks a judicially cognizable interest in the prosecution or nonprosecution of another."); see also Cardenas, supra note 4, at 375.

This proposal does not address victims' inability to appeal prosecutorial decisions not to prosecute. Several states do provide victims with himited access to private prosecution, although typically the private prosecutor must work under the control of the district attorney. Aynes, supra note 11, at 98-99 and un.173-74; McDonald, supra note 5, at 665 n.78.

One commentator recently suggested allowing victims in imminent danger of revictimization by the same offender to seek a judicially initiated prosecution in the event of nonprosecution by the public attorney. Comment, Judicially Initiated Prosecution: A Means of Preventing Continuing Victimization in the Event of Prosecutorial Inaction, 76 CAL1F. L. REv. 727 (1988) (authored by Kenneth L. Wainstein).

132. See P. Dow, supra note 130 , at 104-06.

133. United States v. Lovasco, 431 U.S. 783, 794 (1977). 
outcoine, the veto will not interfere with judicial sentencing discretion. This Comment does not propose to grant victims any power over judicial sentence determinations, even if a judge inodifies a negotiated offer to which a victim has previously agreed. The sentencing judge is free to reject any disposition decision reached by the victim, prosecutor and defendant. ${ }^{134}$ Further, the legislature has prescribed a sentencing range for the crime charged within which both the victim and the judge inust operate. A victim has no authority to require a penalty not provided by statute. Limiting the veto to the plea bargaining context therefore empowers the victim without jeopardizing the rights of the defendant, intruding on judicial sentencing authority, or excessively hampering prosecutorial discretion.

\section{b. Increasing Prosecutorial Accountability}

The flip side of decreased prosecutorial discretion is increased accountability. When a prosecutor must explam to an mjured victim the rationale behind a prosecutorial decision, the victim learns how the criminal justice system works, and is reassured that the process operates fairly and openly. A prosecutorial decision that cannot be justified to the victim is in all probability based upon illegitimate considerations.

In fact, several states already require prosecutors to be accountable to the victims whose interests they represent. Seven states have statutes that require prosecutors to consult the victim before they present a plea to the court. ${ }^{135}$ Six other states require that the judge consult the victim before accepting a plea. ${ }^{136}$ Even in states that do not have a statutory

134. See United States v. Moore, 637 F.2d 1194, 1196 n.3 (8th Cir. 1981) (noting that adoption of 1974 amendments to Rule 11 of the Federal Rules of Criminal Procedure increased federal district court discretion in dealing with guilty pleas, and that the court was not obligated to consider a negotiated plea agreement); United States v. Ammidown, 497 F.2d 615, 622 (D.C. Cir. 1973) (court can rejeet a plea if the prosecutor has failed to consider "factors that inust be given consideration in the pubhic interest.").

135. Johnson, Crime Victims Getting A Day, and a Say, in Court, N.Y. Times, Apr. 1, 1988, at 23, col. 3. A representative statute froin Kentucky states, in relevant part: "The victim shall be consulted by the attorney for the Commonwealth on the disposition of the case including dismissal, release of the defendant pending judicial proceedings, a negotiated plea, and entry into a pretrial diversion program." Ky. REv. STAT. ANN. $\$ 421.500(6)$ (Michie/Bobbs-Merrill Supp. 1988); see also Mich. COMP. LAws ANN. § 780.756(3) (West Supp. 1988); MONT. CODE ANN. § 46-24-104 (1987); N.Y. EXEC. LAW § 642(1) (McKinney Supp. 1988); S.C. CODE ANN. § 16-3-1530(C)(12) (Law. Co-op. 1985); S.D. CoD1FIED LAwS ANN. § 23A-7-8(4) (1988); W. VA. CodE § 61-11A6(a)(5) (1984).

136. Johnson, supra note 135; see, e.g., CoNN. GEN. STAT. § 54-91c(c) (Supp. 1988), which states, in relevant part:

"Prior to the ... acceptance of a plea pursuant to a plea agreenient, the state's attorney ... shall advise the victim of such crime of the date, time and place of . . . any judicial proceeding concerning the acceptance of a plea pursuant to a plea agreeinent, provided the victim has informed such state's attorney ... that he or she wishes to make or submit a statement as provided in subseetion (b) of this section ....." 
policy requiring victim consultation, prosecutors have occasionally granted victims informal veto power over prosecutorial decisions. ${ }^{137}$

\section{c. Providing a Superior Alternative to the Civil System}

As a policy matter, a proposal that permits victims to affect criminal case dispositions is likely to be criticized for distorting the legal balance between criminal and civil actions. Those who believe that the current legal conception of crime as an offense against the state and not against the individual victim reflects the correct balance of state and individual interests will undoubtedly feel that victim participation in the criminal disposition process should be limited to appearances as witnesses on behalf of the state, and that a victim's grievances against an offender are best handled in a separate civil suit.

Yet this theoretical distimction fails to recognize that, as a practical inatter, victims usually are unable to obtain rehef through civil actions, since the majority of criminal defendants are judgment-proof. ${ }^{138}$ Victims therefore must choose between two forms of impotence: the frustration of standing helplessly by while a criminal bargains with the prosecution, or the futility of brimging a civil action.

It is important to recall that the exclusion of victims from the process of criminal adjudication is relatively recent and is contrary to the system's original focus on the victim as a primary actor. This shift has produced growing victim dissatisfaction with the system and frequent failure to report crimes. ${ }^{139}$ Some victims resort to self-help in the behef that the criminal justice system has becone ineffective. ${ }^{140}$ The rise of the Victims' Rights Movement suggests that the purposes of the criminal justice systein inay be better effectuated by returning victims to a inore prominent role in criminal prosecutions. ${ }^{141}$

Even absent such a statute, judges may hear statements from victims or their representatives at the time of sentencing regarding their opinion of a plea agreement. For a case in which the victim's representative was instrumental in persuading a judge to reject a plea agrecment, see the discussion of People v. Stringham, supra at note 84.

137. For example, the Delaware legislature defeated a victim consultation bill in 1987. However, Charles Oberly, Delaware's Attorney General, has iniplemented a formal office policy that no guilty plea to a reduced charge may be accepted in a felony case unless the victim has first been consulted. Johnson, supra note 135.

138. See Schultz, The Violated: A Proposal to Compensate Victims of Violent Crime, in CONSIDERING THE VICTIM, supra note 1, at 133-34.

139. See supra notes $45-46$ and accompanying text.

140. "[W] $]$ hen people beheve the criminal justice system cannot or will not control crime, we see the return to earlier methods of 'law enforcement' - feuds, mob action, and the like." $R$. FINE, ESCAPE OF THE GU1LTY 10-11 (1986) (citing the case of Bernhard Goetz as an example).

141. Reversing the trend of victim exclusion from the criminal justice system may be justified as an extension of social contract theory. Under this theory, individuals in an ordered society give up their natural right to protect theinselves from crime and to avenge crines through self-help by granting the goverument a monopoly on the use of punitive force. See genterally J. LockE, Second 
Finally, increasing victim impact on criminal dispositions will not necessarily disturb the current delicate balance of state and individual interests. Victim participation is, of course, constrained by the Constitution and, perhaps to an even greater extent, by the limited resources of the criminal justice systein itself. Any proposal to increase victim impact on case dispositions must have the dual virtues of constitutionality and practical efficiency, or prosecutors will refuse to adopt it.

\section{d. Permitting Victim Leniency: The Myth of Victim Retributiveness}

Critics nay argue that it is inappropriate to involve victins in the pretrial disposition process because those victims who participate will inevitably be motivated by a desire for retribution and will uniformly press for harsher punishment of offenders. ${ }^{142}$ They may question whether affording victims the opportunity to vent their personal desires for vengeance serves any constructive purpose. ${ }^{143}$

That observers inay assunie that crime victims are notivated by a desire for vengeance is understandable. However, commentators have

Treatise of Civil Government, in THE TRADITION OF FREEDOM 5-7 (M. Mayer ed. 1957) (humans in the state of nature redress their own grievances, but society has put the common right of punishment, shared by all, in the hands of the magistrate).

In return, the state assunies responsibility for the reasonable protection of its citizens and also becomes the sole instrument of retributive justice. According to one legal scholar, the "government's monopoly on the use of force carries with it the duty to protect its citizens from attack and theft." Hudson, supra note 71, at 31 (footnote omitted); see also Aynes, supra note 11, at 64-65. Aynes argues that this duty of reasonable protection gives crime victims standing to sue government officials for negligence. Id. at 115-16.

The occurrence of a crime that the state could reasonably have prevented therefore represents a breach of the government's contractual duty to protect its citizens. Once such a crime has occurred, the state should be required to mend the breach by permitting some degrce of victim participation in the prosecution of the offense. If one considers the granting of a measure of victim participation to be a condition of the state's successful fulfillment of its contractual obligation following the breach, the current practice of excluding the victim seems questionable. As Norval Morris has said:

[I]f the crimimal process is the taking over by the state of the vengeful instincts of the injured person-buttressed by the rccognition that the harm to the victim is also harm to the state-then ... the victim at least has a right to be informed of, and where appropriate involved in, the processes that have led to whatever is the state settlement of the harm that has been done to him. ... [1]t is a matter of courtesy and respect to the dignity of the individual victim. If his acceptance of any compensatory arrangements is to be introjected into the settlement, as it should be more frequently than it is now, his presence is essential. Morris, The Future of Imprisonment, in F. ZIMRING \& R. FRASE, supra note 21, at 639.

Some commentators argue that a breach of the social contract creates a right of victim restitution rather than participation. See, e.g., Wolfgang, Victim Compensation in Crimes of Personal Violence, in CONSIDERING THE VICTIM, supra note 1, at 121 (arguing that the state's failure in its duty to prevent crime gives rise to a right of indemnification to the crime victim).

142. Referring to proposals to increasc victim participation at the sentencing stage, one author argues that "retaliation is the only rationale for the criminal sanction with which victim participation ... [is] consistent ...." Henderson, The Wrongs of Victim's Rights, 37 STAN. L. REV. 937, 1001 (1985).

143. See id. at 998 ("Forgiveness, rather than vengeance may, therefore, be the act that eventually frees the victim from the event ...."). 
pointed out that no evidence supports the assumption that victims uniformly seek harsh penalties. ${ }^{144}$ In fact, the evidence is to the contrary.

A 1981 case study of one hundred criminal cases found that, when victims of various crimes were given the opportunity to select from several viable sentencing alternatives, all but one were willing to accept an alternative to incarceration. ${ }^{145}$ In addition, a study of 417 sexual assault victims in a metropohtan Ohio county revealed that victims who implicitly recognized that they had played some role in the offense had a shight tendency to make lenient sentencing recommendations. ${ }^{146}$ Moreover, when the defendant was not a repeat offender, these victims' recommendations of leniency influenced the judge's ultimate sentencing decision. ${ }^{147}$

Finally, the experimental program in Florida that permitted crime victims to sit in on pretrial settlenient conferences revealed that victims generally did not deinand the maximun 1 authorized punishment and most often concurred with the disposition the attorneys proposed. ${ }^{148}$ The available evidence therefore suggests that involving crime victims in the criminal disposition process will not necessarily encourage retributive attitudes. If anything, many victims may exercise their influence in the direction of leniency.

Although soine victims undoubtedly will be motivated by a desire to obtain harsher sentences, their retributive urges will effectively be constrained by the statutory sentence maximums set by the legislature. These sentencing ranges represent a legislative determination of the appropriate level of pumshment for the crimie charged, once aggravating and mitigating circumstances are taken into aceount. While statutory sentence ranges are commonly criticized as overly harsh, ${ }^{149}$ sentencing reform is a matter for the legislature. Individual victims seeking only to enforce a criminal statute cannot be blamed for the undue harshness of the statutory sentencing ranges.

144. Kelly, supra note 42 , at 21 ; see also M. BARD \& D. SANGREY, supra note 41 , at 128 ("Many victims have reservations about sending anybody to prison because they believe that prison conditions are brutalizing and encourage criminal behavior.").

145. See Henderson \& Gitchoff, supra note 113, at 230.

146. Walsh, supra note 76 , at 1133 .

147. See id. at 1140 (finding that if a victim recommended probation and probation was legally warranted, that recommendation tipped the scale in favor of an award of probation).

148. Heinz \& Kerstetter, supra note 95, at 172.

149. See Frankel, supra note 127, at 106-07 (arguing that legislators acting in "righteous indignation" will enact sentencing ranges with little thought or attention given to maximum penalties that judges can impose in their discretion); Rosett, supra note 128, at 21 ("[O]ur criminal law is so harsh that its full application in all but aggravated cases would not only be cruel, but also expensive and socially destructive."). 


\section{e. Expanding Prosecutorial Consideration of Victim Characteristics to Include Victim Preferences}

One might argue that prosecutorial decisions should not be affected by characteristics of the victim, such as a victim's assertiveness in opposing a prosecutor's plea offer. Rather, legitimate prosecutorial decisionmaking should be based on the strength of the evidence, the characteristics of the defendant, and the nature of the crime.

However, as a practical matter, prosecutors currently do assess the characteristics of victims when making prosecutorial decisions. In assessing how best to allocate the scarce resources of the criminal justice system, prosecutors inevitably must consider the seriousness of the crime, its importance to the community, and the likelihood of conviction-all of which are related, at least in part, to victims' personal characteristics. For example, prosecutors tend to base decisions regarding how strongly to press a case or whether to bargain in part on their assessment of how a jury will perceive the victim. "[T]he character and credibility of the victim is a key factor in determining prosecutorial strategies, one at least as important as 'objective' evidence about the crime or characteristics of the defendant."150 Prosecutors also consider victim attributes when deciding whether to offer a plea bargain, although they often do not consider victims' attitudes toward the plea itself. ${ }^{151}$ Thus, the proposal does not depart significantly from current practice.

Moreover, there may be compelling pohicy reasons for requiring prosecutors to consider victims' characteristics at the pretrial stage. The character of the victim or the impact of the crime inay reveal inportant information about the level of intent or malice associated with the offense. The presence of the victim may also sensitize prosecutors to the commumity's interests, and prevent them from bargaining strictly on the basis of efficiency. Victims, then, may serve as representatives of the community and as a source of important information at a critical stage of the disposition process.

\section{f. Funneling Resources Toward Participating Victims}

The victim's veto anay, if frequently exercised, result in more cases

150. Stanko, The Impact of Victim Assessment on Prosecutors' Screening Decisions: The Case of the New York County District Attorney's Office, 16 LAw \& Soc'Y REV. 225, 226 (1981-82); see also McDonald, supra note 43, at 42 (describing the prosecutor's "ideal victim" as a "clean-cut, polite war veteran with a Purple Heart for losing an arm while saving a buddy.").

151. A study of prosecutorial decisionmaking revealed that, in a simulated robbery case, while prosecutors considered the victim's characteristics $48.6 \%$ of the time and the victim's account of the mcident $72.5 \%$ of the time, they only considered the victim's attitude toward a plea bargain $42.8 \%$ of the time. Rossman, McDonald \& Cramer, Some Patterns and Determinants of Plea-Bargaining Decisions: A Simulation and Quasi-Experiment, in PLEA-BARgAINING, supra note 70, at 84-85. 
proceeding to trial. ${ }^{152}$ Trials are expensive and significantly drain the scarce resources of the criminal justice system. In addition, smce sentences meted out after trial are generally harsher than those obtained following a plea of guilty, ${ }^{153}$ the strained resources of the correctional system will be disproportionately commanded by criminals whose mjured victims chose to exercise a veto and force a trial, as opposed to those criminals who committed "victimless" crimes or whose victims were more ainenable to prosecutorial suggestion.

This potential shift im the expenditure of resources is justified, however. The disposition of the victim has always played an important role im allocatimg resources; indeed victims can completely control the role of the prosecutor by refusing to press charges altogether. Furthermore, it seeins particularly reasonable to involve victims in resource allocation because by their very existence they implicate a greater claim to prosecutorial action. Our society devotes more resources to prosecuting crimes that have identifiable victims because of the traditional value we place on the protection of persons over property. For exainple, a person can legally defend against a threat of serious bodily injury by using deadly force, but may not use deadly force to prevent loss of, or damage to, property. ${ }^{154}$ In addition, crimes against persons are prosecuted more vigorously than crimes against property and victimless crimes. ${ }^{155}$ These

152. Any conclusion about the effect of the victim's veto on trial rates must necessarily be tentative. This is because the defendant is still free to plead guilty to the crime charged, even if no plea bargain is offered, in the expectation that this will result in a nore lenient sentence than might be received after conviction at trial. For evidence suggesting that this expectation is well-grounded in reality, see infra note 153 regarding the so-called "trial tariff."

Furthermore, even though the veto may increase trial rates, this does not necessarily result im case backlog. In jurisdictions that have eutirely abohshed plea bargaining, the effect on disposition time has varied considerably. Compare Daudistel, On the Elimination of Plea-Bargaining: The El Paso Experiment, in PLEA-BARGAINING, supra note 70, at 71 (elimination of plea bargaining caused a serious case backlog) with Rubinstem \& White, Alaska's Ban on Plea-Bargaining, in id. at 45 (ban on plea bargaining resulted in an increase in trials, but did not result in backlog).

153. The difference between sentences received after pleading guilty and those received after trial is commonly known as the "trial tariff." See F. ZIMRING \& R. FRASE, supra note 21, at 561. See generally Kipins, Criminal Justice and the Negotiated Plea, in id. at 520 (citing annual statistics published by the Administrative Office of the U.S. Courts, which found that in 1970, defendants who pled guilty received average sentences of probation and/or less than one year in prison, while defendants convicted after a jury trial received average sentences of three to four years im prison); see also Note, Restructuring the Plea Bargain, 82 YALE L.J. 286, 301 (1972) (suggesting the use of a uniform "specific discount rate" that judges would apply to the probable trial sentence when sentencing defendants who plead guilty, as an alternative to the inequitable and unpredictable "trial tariff").

154. See, e.g., State v. Metcalfe, 203 Iowa 155, 212 N.W. 382 (1927); see also W. LAFAvE \& A. SCOTT, CRIminal LAw 456 (2d ed. 1986) (noting that use of deadly force is not rcasonable to prevent threatened harm to property, because "the preservation of human hife is more important to society than the protection of property." Id. at 466.).

155. See Vera Institute of Justice, Felony Arrests: Their Prosecution and Disposition in New York City's Courts, in F. ZIMRING \& R. FRASE, supra note 21, at 287 (presenting a graph that indicates 
examples illustrate a longstanding societal concern with the protection of persons that justifies the expenditure of relatively inore resources on crimes involving victims. ${ }^{156}$

\section{Practical Analysis of the Proposal}

The foregoing discussion suggests that the victim's veto is both constitutional and would advance important public pohicy concerns. Nevertheless, soine have argued that such a proposal would be administratively unwieldy or impractical. The following discussion explores these practical concerns.

\section{a. Prosecutorial Resource Concerns}

Practicing district attorneys presented with this proposal expressed several misgivings. ${ }^{157}$ Their foreinost objection was that einpowering crime victims with a binding veto would cause additional delays in an already overburdened systein. Contrary to what one might expect, these prosecutors were not primarily concerned with delays caused by victims' presumed desire for retribution and the resulting inclination to press for trial rather than settleinent, although this was mentioned. ${ }^{158}$ Instead, they were most concerned that notifying and consulting victims would require additional staff time.

This additional burden, though certainly real, is not insurmountable, and is justified by the importance of granting victims an effective impact on case dispositions. Administrative costs can be minimized, either through carefully drafted procedures or through delegation of certain aspects of the notification task.

In theory, prosecutorial case inanagement time would increase only if a victim disagrees with a disposition offer. ${ }^{159}$ The available research indicates that inany victims tend to agree with proposed dispositions, ${ }^{160}$

that pleas to a misdemeanor or lesser felony are permitted less often when the felony charged is a crime of violence than when the felony involves property or is a victimless crime).

156. Recall that resources will only shift toward those defendants who injure victimus exercising a veto. This raises the question whether a shift im resources away from crimes against nonprotesting victims and toward crimes against protesting victinıs is justifiable. This Comment contends that victim satisfaction with the criminal justice system is vital to its continued operation. See supra notes $40-46$ and accompanying text. Spending more to prosecute crimes involving protesting victims can therefore be justified on the grounds that the system should be especially attentive to dissatisfied victims if it hopes to ensure their present and future cooperation.

157. On March 17, 1988, this proposal was informally presented to a group of assistant district attorneys in the Felony Preliminary Hearing department of the San Francisco District Attorney's office. Comments in the text that are attributed to practitioners were taken from notes made during this discussion.

158. For a response to this criticism, see supra notes 144-148 and accompanying text.

159. Of course, prosecutorial interaction with crime victims is highly desirable and should be encouraged throughout the disposition process to the extent that resources permit.

160. See supra text accompanying note 101 . 
and thus prosecutors would have to explain the rationales behind their offers to only that minority of concerned victims who disagree with their terms. Furthermore, many of the victims who imitially feel displeased with a proposed disposition will probably be persuaded to agree once they understand the rationale behind the proposed settlement.

The fact that a relatively small number of victims may actually be sufficiently dissatisfied with disposition offers to exercise a veto does not undermine the tremendous importance of establishing an effective means for those victims to express their concern. The beneficial effect of satisfying even one victim is magnified by the impact that victim's satisfaction will have on those who observe it. The victim's family, friends, and community will feel reassured that the system will take their needs into consideration shonld they be victimized. This reassurance shonld translate into increased reporting and participation by these citizens as well as by individuals who are revictimized. Furthermore, the increased visibility of the plea bargaining process obtained through victim participation will legitimate plea bargaining in the skeptical mind of the public.

The anticipated infrequency with which victims will exercise the veto indicates that this reform can be implemented with only a minimal burden on criminal justice resources. By integrating victims into the process and empowering them, the proposal would increase victim satisfaction, regardless of whether they exercise the veto.

\section{b. Professional Competence, Autonomy, and Integrity}

Practicing prosecutors also objected to having to justify to victims a decision that in the past has been within their exclusive discretion. The issue for these attorneys was one of professional autonomy and integrity. They argued that their experience and expertise uniquely qualify them to craft an appropriate offer. They felt that a procedure that forces them to justify their decisions to victims and to act in a manner potentially mconsistent with their professional judgment would undermine their sense of professional competence. One district attorney likened this proposal to a patient insisting that a physician perform a certain surgical treatment in heu of a procedure that the doctor recommended as more medically appropriate.

The physician-patient relationship is distinguishable, however. First, unlike physicians, who are individually responsible for their treatment decisions, it is usually office policy and not an individual attorney's expertise or experience that determines whether a prosecutor offers a plea bargain and what that offer consists of. ${ }^{161}$ Therefore, prosecutors are

161. See J. JACOBY, supra note 10, at 199 (citing a 1976 study that found that different prosecutors' offices manifest distinctive patterns of disposition, resource allocation, and negotiation strategies); P. UTZ, SETTLING THE FACTS 47, 64-65, 104-06 (1978). Utz compared plea negotiations 
hardpressed to argue that abiding by victims' wishes interferes with some notion of individual professional competence and autonony.

In addition, while a patient who disagrees with a doctor's recoinmendation can always change physicians to secure a desired treatment, the crime victim cannot change prosecutors, since the state holds a virtual monopoly on prosecutorial power. As a rule, a victim cannot appeal a district attorney's decision not to prosecute. ${ }^{162}$ Although the victim is essentially at the mercy of the district attorney's office, the prosecutor has no similar obligation to the victim. Requiring victims to accept decisions made in the exercise of considerable and unreviewable discretion, by prosecutors who do not necessarily represent the victims' best interests, ${ }^{163}$ seems a high price to pay for prosecutorial autonomy. The victim's veto offers a reasonable compromise of these competimg interests.

\section{c. The Spectre of the Unreasonable Victim}

Requiring prosecutors to acknowledge victims' interests inevitably raises the spectre of the unreasonable victim who presses for a harsher sentence or pushes for trial despite prosecutorial protests that a ease is unwinnable. However, the available evidence suggests that this will not be a common problem. ${ }^{164}$ In addition, it is precisely those victims strongly motivated by punitive urges who are most likely to be persuaded by a prosecutor's argument that a trial will result in no conviction at all, while a settlement will ensure at least soine measure of retribution.

Finally, it is important to keep in mind that the worst harm that an unreasonable victim can cause is the enforceinent of an obligation the prosecution lias already assumed by filing criminal charges: the burden of proving its case at trial. The state is currently unable to shirk this obligation when faced with an unreasonable defendant or a defense attorney who refuses to negotiate. To allow the victim to put the state to its proof therefore does not impose a new or additional burden on the district attorney. It simply adds one inore person to the hist of those who can enforce a burden the prosecution already bears.

\section{CONCLUSION}

This Cominent has reviewed the historical background that led to

\footnotetext{
in two district attorney's offices in California, and noted that prosecutors' offers were closely supervised and scrutinized in one office, whereas the other office had a policy of encouraging prosecutorial flexibility in negotiations and granted its attorneys more autonomy in plea bargaining. For an example of an explicit prosecutorial office policy regarding plea bargaining, sec Kuh, Plea Bargaining: Guidelines for the Manhattan District Attorney's Office, 11 CR1M. L. BULL. 48 (1975).

162. See supra note 131 and accompanying text.

163. R. ELIAS, supra note 5, at 150; Aynes, supra note 11, at 73 \& n.40; supra note 132 and accompanying text.

164. See supra notes $144-148$ and accompanying text.
} 
the current exclusion of the crime victim from the criminal justice system. It has argued that this trend toward excluding the victim should be reversed $\mathrm{m}$. hight of heightened public concern with crime and crime victims. This renewed concern springs from several factors, including the failure of rehabilitation and the rise of the Victims' Rights Movement.

To help reverse this trend, this Comment has presented a proposal for empowering victims by allowing them to have an actual impact on disposition decisions in criminal cases. It proposes the adoption as prosecutorial policy of a bimding veto that crime victims can exercise during pretrial negotiations in the event of an unsatisfactory prosecutorial disposition offer. Such a veto gives crime victims an effective voice in the outcome of their criminal cases and increases victim satisfaction with the criminal justice system. This in turn should lead to improved victim reporting of crimes and improved participation in the process of criminal justice. Perhaps most significantly, however, the veto has substantial symbohic importance, as it finally recognizes the reemergence of crime victims as prominent actors in the criminal justice system. 
